\title{
THE GENETIC DIVERSITY OF KEJOBONG GOAT BASED ON CYTOCHROME B GENE
}

\author{
Jiyanto, Sutopo and E. Kurnianto \\ Faculty of Animal and Agricultural Sciences, Diponegoro University, \\ Tembalang Campus, Semarang 50275 - Indonesia \\ Corresponding E-mail:aji_jiyanto16@yahoo.com \\ Received March 28, 2014; Accepted May 22, 2014
}

\begin{abstract}
ABSTRAK
Tujuan penelitian ini adalah untuk mengidentifikasi kambing Kejobong berdasarkan keragaman gen Cytochrome b dengan teknik Polymerase Chain Reaction (PCR)-Sekuensing dan mengetahui hubungan kekerabatan antar bangsa kambing melalui pohon filogeni. Materi penelitian adalah sampel darah 12 ekor kambing Kejobong yang berasal dari Kecamatan Kaligondang, Pengadegan, Kejobong, dan Bukateja. Tahapan penelitian meliputi extraksi DNA, PCR, elektroforesis, dan sekuensing DNA. Primer forward 5'-tggaatctaaccatgaccaatg-3' dan reverse 3'-ggctattctccttttctggttt-5' digunakan pada proses PCR. Hasil sekuensing dianalisis dengan menggunakan ClustalW dalam program MEGA 5. Hasil penelitian menunjukkan bahwa DNA dapat diextraksi dengan baik, dengan hasil 779 bp pada nukleotida ke 238-1016 di daerah Cytochrome b. Setelah dilakukan analisis penjajaran, diperoleh 7 situs kodon yang beragam (103, 122, 165, 167, 198, 215 dan 284) pada kambing Kejobong. Terjadi perubahan asam

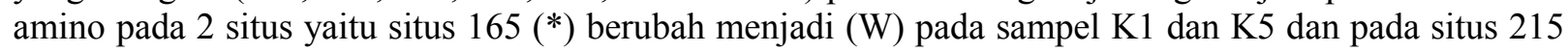
(T) berubah menjadi (A) pada semua sampel kambing Kejobong. Kambing Kejobong dari 4 Kecamatan memiliki jarak genetik yang rendah $(0,000-0,001)$. Analisis DNA mitokondria pada gen Cytochrome $b$ Kambing Kejobong yang berasal dari tempat berbeda menunjukan kemiripan yang tinggi dan hubungan kekerabatan yang dekat.
\end{abstract}

Kata kunci: Cytochrome b, kambing Kejobong, nukleotida, asam amino, hubungan genetik

\begin{abstract}
The purpose of this research was to identify Kejobong goat based on Cytochrome b gene variation by Polymerase Chain Reaction (PCR)-Sequencing technique and to analyze the genetic relationship by using phylogenetic tree. Materials used were blood sample of 12 heads of Kejobong goat from Kaligondang, Pengadegan, Kejobong, and Bukateja Districts. The steps of this research included DNA extraction, PCR, electrophoresis and DNA sequencing. Forward primer 5'-tggaatctaaccatgaccaatg-3 'and reverse 3'-ggctattctccttttctggttt-5' were used in PCR process. The results of sequences were then analyzed by ClustalW in the MEGA 5. The result of this study showed that DNA could be extracted well. The good results obtained from sequenced for about $779 \mathrm{bp}$ at the nucleotide of 238 to 1016 in Cytochrome b. A total of 7 codons diverse sites were detected (sites of $103 ; 122 ; 165 ; 167 ; 198 ; 215$ and $284)$ at Kejobong goats. There was change in amino acid at 2 sites, those were at 165 sites $(*)$ replaced by (W) in K1 and K2 samples, and at 215 sites (T) replaced by (A) in all samples of Kejobong goats. Kejobong goats at 4 Districts had low genetic distance (0.000-0.001). The analysis of Cytochrome $b$ gene of Kejobong goats originated from different area showed the high similarity and a close genetic relationship.
\end{abstract}

Keywords: Cytochrome b, Kejobong goats, nucleotides, amino acid, genetic relationship 


\section{INTRODUCTION}

Kejobong goat was a local goat existing in Purbalingga Regency of Central Java. The origin of Kejobong goat has not been known certainty yet, but phenotypically Kejobong goat is postulated to be a cross between a goat of Ettawa Grade and local goats. Therefore, it is important to study the genetic molecular of Kejobong goat. Kejobong goat was selected by farmers and maintained from generation to generation. Eventually, goat has dominant in black coat color. Therefore, these goats were often called as the black Kejobong goat. The Kejobong ewe has high productivity, often prolific, and a short kidding interval (Sodiq and Haryanto, 2007).

In 2013, Kejobong goat population in Purbalingga Regency was 43,708 head (Dinas Peternakan dan Perikanan Purbalingga, 2013). Kejobong goats have been genetically adapted to environmental conditions and are expected to become more productive. Kejobong goat was able to utilize local feed (Socheh et al., 2011). The birth rate of Kejobong goat is high if reared in a good management. Kejobong goat is a meat type goat that is preferred by consumers. The problems occurred in Kejobong goat is the difficulty of breeding implementation. This is because of slaughtering or selling of goats at the young age. If this happens continuously for a long time without any genetic conservation, then extinction is possible to be occurred.

To avoid the extinction of Kejobong goat, the breeding program to preserve genetic is necessary to be done. Genetic status of Kejobong goat has not been known certainty yet, so it is important to study the genetic molecular of Kejobong goat. One effort should be done is to generate the genetic diversity information (Susilowati, 2008). Analysis of DNA mitochondrial (mtDNA) is one of method mostly used to study the origins of domesticated animal (Machugh and Bradley, 2001). In mammalian, mitochondrial DNA is only passed down through the mother (maternal) without recombination (Manceau et al., 1999).

The objectives of this study were to identify Kejobong goat based on Cytochrome b, to analyze genetic distance among Kejobong goats from different districts, and to analyze genetic relationships between Kejobong and Genbank's comparator goats.

\section{MATERIALS AND METHODS}

\section{Materials}

This research was conducted in Purbalingga Regency, Central Java. The blood samples of Kejobong goats designated as K1, K2, K3, K4, $\mathrm{K} 5, \mathrm{~K} 6, \mathrm{~K} 7, \mathrm{~K} 8, \mathrm{~K} 9, \mathrm{~K} 10, \mathrm{~K} 11$, and $\mathrm{K} 12$ were from four districts, those were Kaligondang, Pengadegan, Kejobong and Bukateja. Unfortunatly, there were no other goat breed sample.

\section{Procedure}

The blood samples taken were analyzed in the Laboratory of Biochemistry Faculty of Veterinary Medicine, Gadjah Mada University. The research was included DNA extraction, Polymerase Chain Reaction (PCR), and electrophoresis by using the method of Sambrook et al. (1989) with modification. Mini Kit DNA Genominic of GeneAid was used for extraction. A total of $400 \mu \mathrm{L}$ of blood samples were inserted into Eppendorf tube $1.5 \mathrm{ml}$. Then, the RBC Lysis Buffer was added to reach a volume of $1.5 \mathrm{ml}$ and was waited for $10 \mathrm{~min}$. The samples were then centrifuged at $3.000 \mathrm{rpm}$ for $5 \mathrm{~min}$. Pellet formed at the bottom of the tube was taken and transferred into the new Eppendorf tube. The 200 $\mu \mathrm{L}$ of GT Buffer solution added by $20 \mu \mathrm{L}$ Proteinase-K were inserted into that tube and were fortexed until achieve homogeneity. Samples were incubated in a shaking water bath with a temperature of $47^{\circ} \mathrm{C}$ for $16 \mathrm{~h}$. Homogeneous samples were then removed. The $200 \mu \mathrm{L}$ of Guanidin Buffer was inserted into tube, and then the tube was incubated again for $20 \mathrm{~min}$. Samples were then moved into a GD column tube and 200 $\mu \mathrm{L}$ of absolute ethanol were added to the tube. The samples were centrifuged at a speed of $14.000 \mathrm{rpm}$ for $2 \mathrm{~min}$ to obtain a liquid in the bottom of the tube which was then discarded.

The DNA filtered in a tube was added by $100 \mu \mathrm{L}$ of $\mathrm{W}_{1}$ buffer solution. The samples were centrifuged at 14,000 rpm speed for $1 \mathrm{~min}$, and then the liquid formed at the bottom of column was discarded. The $600 \mu \mathrm{L}$ of wash buffer chloroform was added to clean the remaining protein and polysaccharide, then the samples were centrifuged at 14,000 rpm for 1 minute and got rid of the liquid from bottom of colom. The samples were centrifuged again at $14,000 \mathrm{rpm}$ for $3 \mathrm{~min}$ in order to remove the residual ethanol. The $75 \mu \mathrm{L}$ of Elution Buffer was added and then the samples were incubated in room temperature. The samples 
were then centrifuged at $14.000 \mathrm{rpm}$ for $1 \mathrm{~min}$. Addition of $75 \mu \mathrm{l}$ of elution buffer was done and the samples were centrifuged using $14,000 \mathrm{rpm}$ for $1 \mathrm{~min}$. The results of DNA pure were taken and transferred to the new eppendorf tube. The result of DNA extraction was observed by using elektroforesis with ultraviolet light at $\lambda=300 \mathrm{~nm}$.

Amplification of PCR was performed using primers of cytochrome $b$ gene with an oligonucleotide sequence of forward primer 5'tggaatctaaccatgaccaatg-3 and reverse primer 5'ggctattctcettttctggttt-3. PCR amplification was performed with the following conditions: predenaturation in $94^{\circ} \mathrm{C}$ for $5 \mathrm{~min}$, then the amplification reactions of 35 cycles consisted of denaturation process in $94^{\circ} \mathrm{C}$ for $30 \mathrm{sec}$, annealing in $48^{\circ} \mathrm{C}$ for $45 \mathrm{sec}$, elongation at $72^{\circ} \mathrm{C}$ for $1.5 \mathrm{~min}$ and the addition of elongation with $72^{\circ} \mathrm{C}$ for 5 $\mathrm{min}$. The results of PCR were tested by using $1 \%$ agarose gel using electrophoresis (Benzie et al., 2003).

Electrophoresis was performed by using agarose gel. Agarose gel was weighed $0.25 \mathrm{~g}$, and then was dissolved with $25 \mathrm{~mL}$ of TBE in an Erlenmeyer. The agarose and TBE solution were heated for 1 minute in $90^{\circ} \mathrm{C}$ of temperature. Then, the heated solution was cooled into $50^{\circ} \mathrm{C}$. The 3 $\mu \mathrm{L}$ of dye was inserted into solution, and was stirred to obtain homogeneity. The solution was poured in the mold well of gel. The samples and DNA markers were inserted in each well by using a micropipette on agarose gel. Electrophoresis was performed at 90 Volt for $15-30 \mathrm{~min}$ or migration for along $3 / 4$ of the length of the gel. For sequencing, results of PCR products were used as a DNA template for DNA sequencing reaction.

\section{Statistical Analysis}

The base alignment was obtained after sequencing. The sequence was analyzed by using ClustalW (Thompson et al., 1994) in the Molecular Evolutionary Genetics Analysis (MEGA) version 5.0 (Tamura et al., 2007). Alignment was done through a multiple alignment of Cytochrome b of Kejobong goat and other Capra hircus downloaded from GenBank. The Genbank's comparator data used were Capra hircus (AB004075.1), Capra aegagrus (AB004069.1), Capra caucasica (AF034738.1), Capra cylindricornis (AF034737.1), Capra hircus black bengal (DQ073048.1), Capra aegagrus blythi (AB110593.1) and Ovis ammon (AJ867276.1). The genetic distance and relationships among goats were illustrated as a dendrogram using the Unweighted Pair-Group Method with Arithmetic Mean (UPGMA) method.

\section{RESULTS AND DISCUSSION}

One sample (K4) of 12 samples analyzed damaged during sequencing process, so the alignment was done using 11 samples of Kejobong goat with 6 Capra and 1 ovis of Genbank. The aligment result of Cytochrome b gen of Kejobong goat with Capra comparators (779 bp) was found 7 nucleotide sites varied, those were in $309,366,495,501,594,643,852$ bases. The variation among 7 sites might be used to distinguish $\mathrm{K} 1, \mathrm{~K} 2, \mathrm{~K} 3, \mathrm{~K} 5, \mathrm{~K} 6, \mathrm{~K} 7, \mathrm{~K} 8, \mathrm{~K}$, $\mathrm{K} 10, \mathrm{~K} 11$ and K12 with comparator species (Capra in Genbank). In the K2, K3, K6, K7, K8, $\mathrm{K} 9, \mathrm{~K} 10, \mathrm{~K} 11$ and $\mathrm{K} 12$ samples, differentiate codon was shown at the $309^{\text {th }}$ base (Tymine/T replaced by Cytosine/C), the $366^{\text {th }}$ base (Adenine/A replaced by Guanine/G), the $501^{\text {th }}$ base (Guanine/G replaced by Adenine/A), 594 ${ }^{\text {th }}$ base (Cytosine/C replaced by Tymine/T), the $643^{\text {th }}$ base (Adenine/A replaced by Guanine/G), and the $852^{\text {th }}$ base (Cytosine/C replaced by Tymine/T). In the $\mathrm{K} 1$ and $\mathrm{K} 5$ the differentiator codon was not only found as similar to nucleotide bases of $\mathrm{K} 2$, K3, K6, K7, K8, K9, K10, K11 and K12 samples, but also in $495^{\text {th }}$ base (Adenine/A) replaced by Guanine/G).

The Cytochrome $\mathrm{b}$ aligned showing six bases sites that always appear in the Kejobong goat. Those sites exhibited a uniform, but it was different from Capra hircus. Meanwhile, the alignment in samples of Cytochrome $b$ gene in Kejobong goats showed one varied nucleotide. The variation was found in the $495^{\text {th }}$ base sequence in the form of Adenine (A) replaced by Guanine $(\mathrm{G})$. The variation found in nucleotide becomes the accurate parameter to describe the genetic variation. Nucleotide variation is not depending on both sample size and length of the DNA. The small samples were also able to provide more information. The variation of genes can be caused by different levels of substitution among lineages evolution or by genetic consequences of population (Mucci et al., 1998). The Cytochrome b gene variation in Kejobong goats and comparator are presented in Table 1 .

Based on the amino acid sites and triplet codons, the mutation of Cytochrome $b$ gene of Kejobong goat took place from comparator species (Capra hircus). In Table 1, there is a 
Table 1. Diversity in Cytochrome b of Kejobong Goats

\begin{tabular}{|c|c|c|c|c|c|c|c|}
\hline & & & & te to $(C$ & & & \\
\hline & 103 & 122 & 165 & 167 & 198 & 215 & 284 \\
\hline Capra hircus & TAT & GCA & TGA & GGG & CTC & ACA & ATC \\
\hline $\mathrm{K} 1$ & . .C & $\ldots \mathrm{G}$ & $\ldots \mathrm{G}$ & . A & $\ldots \mathrm{T}$ & G. . & $\ldots T$ \\
\hline K2 & . .C & . .G & $\ldots$ & . .A & $\ldots \mathrm{T}$ & G. . & $\ldots \mathrm{T}$ \\
\hline K3 & . .C & $\ldots G$ & $\ldots$ & . .A & ..T & G. . & $\ldots \mathrm{T}$ \\
\hline K5 & . .C & $\ldots G$ & $\ldots G$ & $\ldots \mathrm{A}$ & $\ldots T$ & G. . & $\ldots \mathrm{T}$ \\
\hline K6 & . .C & . .G & $\ldots$ & . .A & $\ldots \mathrm{T}$ & G. . & $\ldots \mathrm{T}$ \\
\hline K7 & . .C & . .G & $\ldots$ & . A & $\ldots \mathrm{T}$ & G. . & $\ldots \mathrm{T}$ \\
\hline K8 & . .C & . .G & $\ldots$ & $\ldots \mathrm{A}$ & .. T & G. . & $\ldots \mathrm{T}$ \\
\hline K9 & . .C & . .G & $\ldots$ & $\ldots \mathrm{A}$ & .. T & G. . & $\ldots \mathrm{T}$ \\
\hline K10 & . .C & . .G & $\ldots$ & . A & ..T & G. . & $\ldots \mathrm{T}$ \\
\hline K11 & . .C & $\ldots \mathrm{G}$ & $\ldots$ & $\ldots \mathrm{A}$ & .. T & G. . & $\ldots \mathrm{T}$ \\
\hline K12 & . .C & . . G & $\ldots$ & $\ldots \mathrm{A}$ & .. T & G. . & $\ldots \mathrm{T}$ \\
\hline Capra aegagrus $\#$ & $\ldots$ & $\ldots G$ & $\ldots$ & . A & $\ldots$ & $\ldots$ & $\ldots$ \\
\hline Capra caucasica & $\ldots$ & $\ldots$ & $\ldots$ & $\ldots \mathrm{A}$ & $\ldots$ & $\ldots$ & $\ldots \mathrm{T}$ \\
\hline Capra cylindricornis ${ }^{\#}$ & $\ldots$ & $\ldots$ & $\ldots$ & $\ldots \mathrm{A}$ & .. T & $\ldots$ & $\ldots \mathrm{T}$ \\
\hline Capra hicus black bengal & $\ldots$ & . G & $\ldots$ & . A & $\ldots$ & $\cdots$ & $\ldots$ \\
\hline Capra aegagrus blythi ${ }^{\#}$ & $\ldots$ & $\ldots$ & $\ldots$ & . A & $\ldots$ & $\ldots$ & $\ldots \mathrm{T}$ \\
\hline Ovis ammon & $\ldots$ & . .G & $\ldots$ & . .A & $\ldots$ & $\ldots$ & $\ldots$ \\
\hline
\end{tabular}

\begin{tabular}{|c|c|c|c|c|c|c|c|}
\hline & \multicolumn{7}{|c|}{ Site to (Amino Acids) } \\
\hline & 103 & 122 & 165 & 167 & 198 & 215 & 284 \\
\hline Capra hircus ${ }^{\#}$ & $\mathrm{Y}$ & $\mathrm{A}$ & $*$ & $\mathrm{G}$ & $\mathrm{L}$ & $\mathrm{T}$ & $\mathrm{I}$ \\
\hline $\mathrm{K} 1$ & . & . & $\mathrm{W}$ & . & . & A & . \\
\hline K2 & . & . & . & . & . & A & . \\
\hline K3 & . & . & . & . & . & $\mathrm{A}$ & . \\
\hline K5 & . & . & $\mathrm{W}$ & . & . & $\mathrm{A}$ & . \\
\hline K6 & . & . & . & . & . & $\mathrm{A}$ & . \\
\hline K7 & . & . & . & . & . & A & . \\
\hline K8 & . & . & . & . & . & A & . \\
\hline K9 & . & . & . & . & . & $\mathrm{A}$ & . \\
\hline K10 & . & . & . & . & . & $\mathrm{A}$ & . \\
\hline K11 & . & . & . & . & . & A & . \\
\hline K12 & . & . & . & . & . & $\mathrm{A}$ & . \\
\hline Capra aegagrus $\#$ & . & . & . & . & . & . & . \\
\hline Capra caucasica $\#$ & . & . & . & . & . & . & . \\
\hline Capra cylindricornis ${ }^{\#}$ & . & . & . & . & . & . & . \\
\hline Capra hicus black bengal & . & . & . & . & . & . & . \\
\hline Capra aegagrus blythi ${ }^{\#}$ & . & . & . & . & . & . & . \\
\hline Ovis ammon & . & . & . & . & . & . & . \\
\hline
\end{tabular}




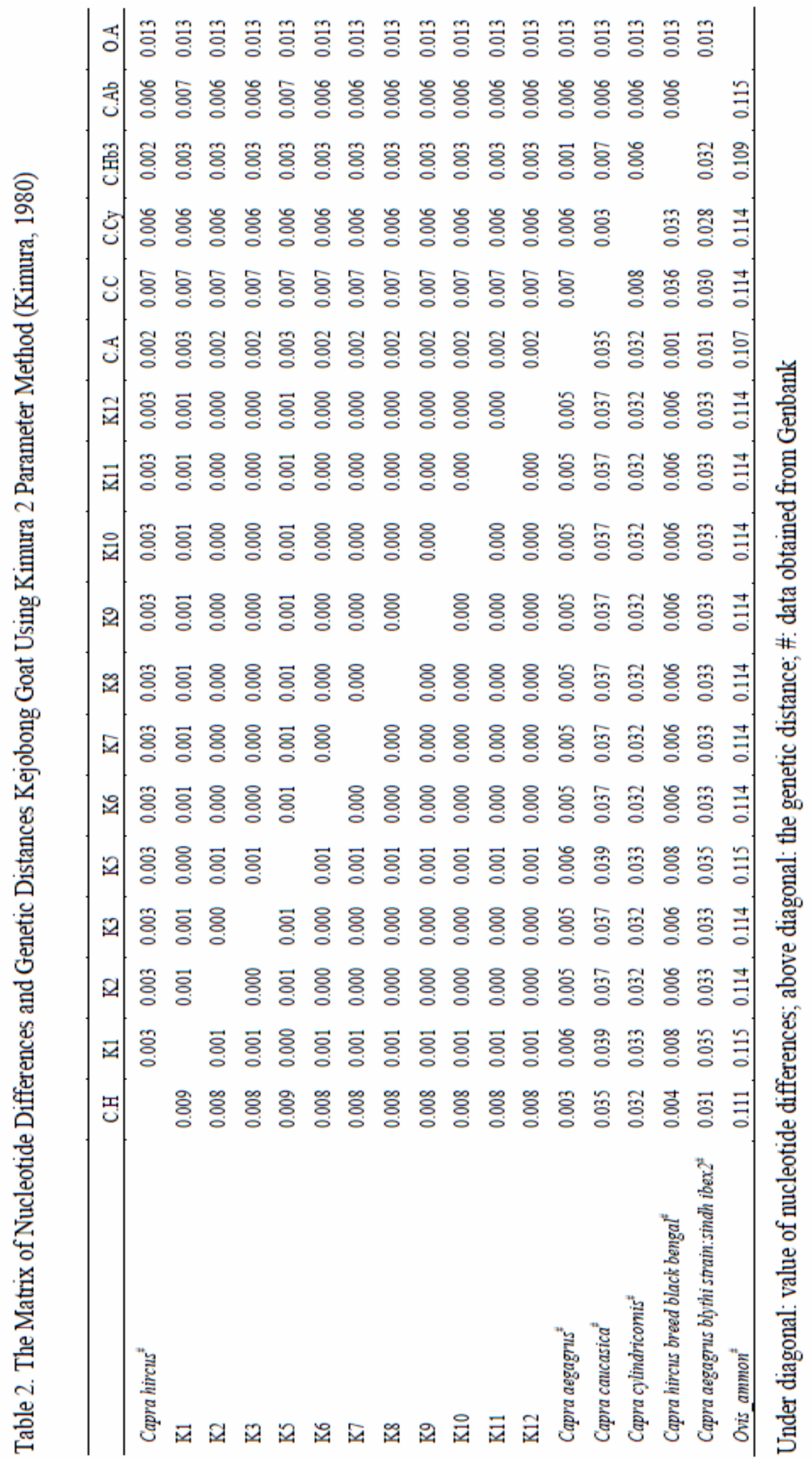




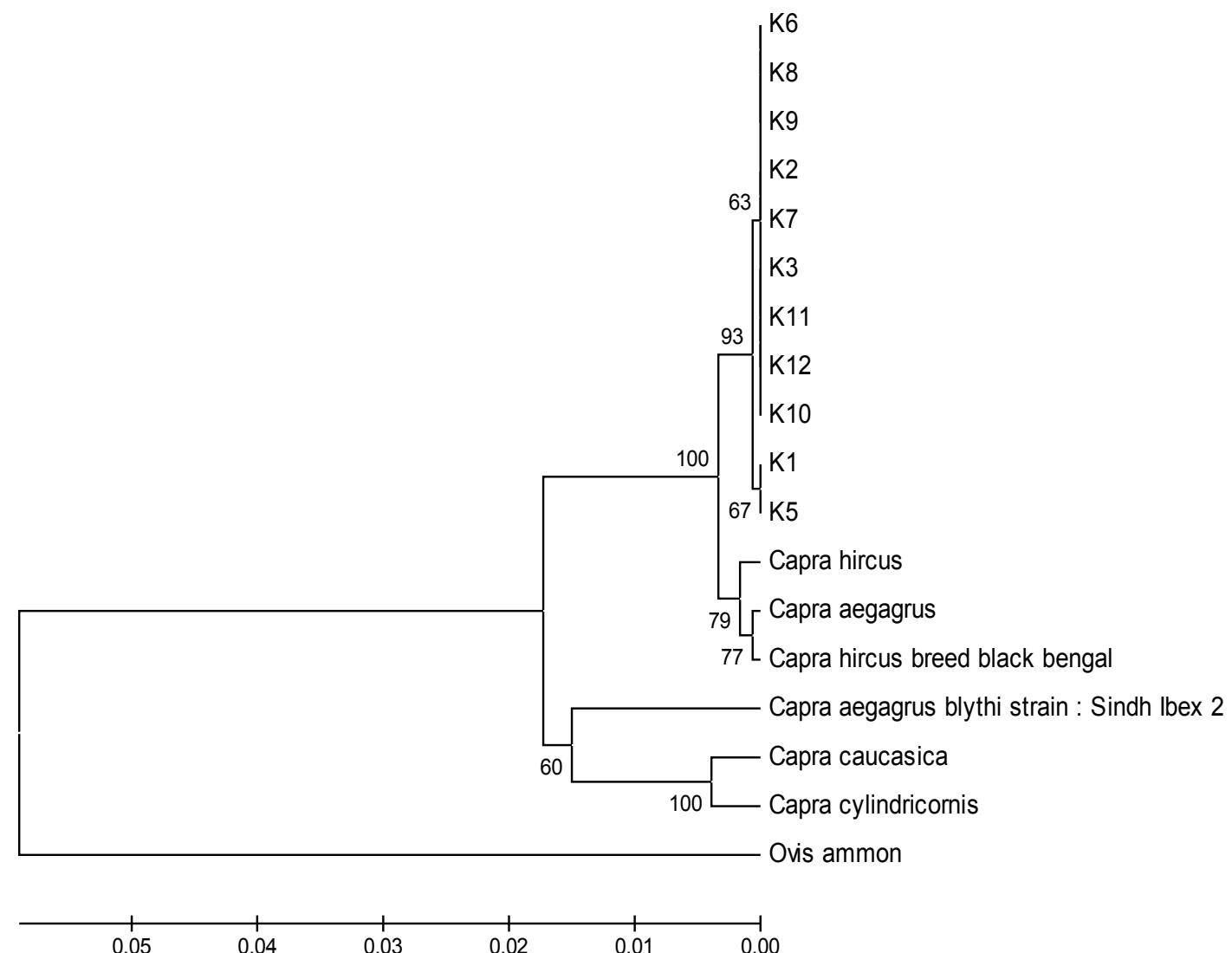

Figure 1. Phylogeny of Kejobong Goat and Some Comparators Goat using UPGMA

difference in sequence codon between Capra hircus and Kejobong goat. The reading of amino acids showed the dominance in amino acid sites, in which in each sequence site on three codons has similar amino acids. As stated by Widayanti et al. (2006), the nucleotide substitution caused amino acids synonymous and non synonymous mutations translated, so that the substituted nucleotide did not always cause amino acid changes. Nucleotides (779 bp) constructing the Cytochrome $b$ gene of Kejobong goat was encoded by 20 amino acids into 259 codon sites. Of the 259 sites indicated that there were 7 codons sites varied. In translation of the seven sites, it was found specific amino acid in $165^{\text {th }}$ and $215^{\text {th }}$ amino acid located at $495^{\text {th }}$ and $643^{\text {th }}$ bases of Cytochrome $b$ nucleotide chain of Kejobong goats. The amino acids at $165^{\text {th }}$ site of Capra hircus and K2, K3, K6, K7, K8, K9, K10, K11 and K12 with form of (*) were replaced by Tryptophan (W) in Kejobong goats (K1 and K5) and $215^{\text {th }}$ of amino acids in Capra hircus that was
Threonine (T) was replaced by Alanine (A) in Kejobong goats (K1, K2, K3, K5, K6, K7, K8, $\mathrm{K} 9, \mathrm{~K} 10, \mathrm{~K} 11$ and K12). These amino acids can be used as a specific marker in Kejobong goats. Cytochrome $b$ gene diversity at the nucleotide, codon and amino acid sites is due to goats which live in different habitats.

Goats have been domesticated long time ago (Machugh and Bradley, 2001). Goat has evolved and survived genetically to adapt to environment after a long time life and breeding. Kejobong goat is a domesticated goat reared intensively by farmers in Purbalingga. Occurrence of Kejobong goat diversity was estimated due to the effect of environment causing change in individual genotype and leading to diversity within population. Livestock in different regions usually have different genetic diversity. Animals in large populations and high genetic diversity would be more sustainable than that in small populations with low genetic diversity (Oka et al., 2011). The high variation in livestock population is the result 
of evolution and determinant component for population in its ability to evolve in the future (Woodruff, 2001).

It can be seen in Table 2, the results of Cytochrome $\mathrm{b}$ gene sequence of the $\mathrm{K} 1, \mathrm{~K} 2, \mathrm{~K} 3$, $\mathrm{K} 5, \mathrm{~K} 6, \mathrm{~K} 7, \mathrm{~K} 8, \mathrm{~K} 9, \mathrm{~K} 10, \mathrm{~K} 11$ and $\mathrm{K} 12$ in Kejobong goats, there were very small differences in nucleotide ( 0.000 to 0.001 ). The low diverse of sites among Kejobong goats and comparator goats were considered being similar. According to Hastarina (2012), small various sites on the sequences of Cytochrome $b$ gene showed high similarity. It was stated by Leary and Booke (1990) that the genetic distances ranged from 0 to 1 , if the genetic distance equal to 0 then two population have close genetic relationship. In contrast, if genetic distance between two population equal to 1 then there is no genetic relationships at all. In this study, there were relationships between Kejobong goat and comparator goats that may be because of same genus. On the basis of Kimura (1980) method, the genetic distances between Kejobong goat and Capra comparator were 0.002-0.007.

The relationships among characters that can be observed in a number of species illustrate the relationships that are known as phylogeny (Nauli, 2012). Phylogeny could analyze the changes occurred in the evolution of organisms (Dharmayanti, 2011). The genetic distance used to construct phylogeny tree in this study was based on the 11 samples of Kejobong goats with 6 Capra and 1 ovis comparators that have been identified. Phylogeny of Kejobong goat with comparators is presented in Figure 1.

Phylogeny tree of Cytochrome $b$ gene nucleotide showed that Kejobong goat made a separated cluster. This separation is supported by the bootstrap value of $93 \%$. Bootstrap value is a benchmark to determine the level of accuracy of phylogeny tree. Bootstrap analysis is a method to test how well the set of model data and bootstrap was supported by the software testing, the branches could be trusted (Dharmayanti, 2011).

The phylogeny of Cytochrome $b$ gene in this study formed two clusters. The first cluster consisted of K2, K3, K6, K7, K8, K9, K10, K11 and $\mathrm{K} 12$. The second cluster consisted of $\mathrm{K} 1$ and $\mathrm{K} 5$. The group of $\mathrm{K} 2$ and $\mathrm{K} 3$ (Kejobong goat in Kaligondang District), K6 (Kejobong goat in Pengadegan District), K7, K8 and K9 (Kejobong goat in Kejobong District) and K10, K11 and K12 (Kejobong goat in Bukateja District) illustrated that Kejobong goats originated from four districts in this study could not be distinguished. It means that Kejobong goats were in the same cluster, so it can be stated that the Kejobong goats had close genetic relationship. The goat which was clustered within one branch of phylogeny was caused by the low sequence substitutions in Cytochrome b gene (Sultana et al., 2003). Formation of the group also occurred in other comparator groups (Capra hircus, Capra aegagrus, Capra caucasica, cylindricornis Capra, Capra hircus black Bengal, Capra and Ovis ammon blythi aegagrus). The formation of these groups occurred because of nucleotide substitutions in Cytochrome b gene.

\section{CONCLUSION}

Kejobong goats in Kaligondang, Pengadegan, Kejobong and Bukateja districts have very small genetic diversity, those were in nucleotide, codon and amino acid sites. Based on the sequence analysis, Kejobong goats showed very small genetic distance value $(0.000-0.001)$ indicating the Kejobong goats originated from different areas have high similarity of cytochrome $b$ gene and showed close relationships. Meanwhile, Kejobong goats have far relationship with Genbank's comparator goats.

\section{ACKNOWLEDGMENTS}

This research was partly funded Bantuan Operasional Perguruan Tinggi Negeri (BOPTN) of Diponegoro University 2014. The authors would like to thank Head of Animal Husbandry Office at Purbalingga regency for allowing the research. Appreciation was given to other researcher members (F. Iskandar, H.F. Suryani, T. Permatasari, Zulkarnain, M.F. Harlistyo and O. Syamyono) for good cooperation during the research.

\section{REFERENCES}

Benzie, J.A.H., C. Smith, and K. Sugama. 2003. Mytochondria DNA reveals genetics differentiation between Australian and Indonesia pearl oyster Pinctada maxima (James 1901) population. J. Shellfish Res. 22:781-787.

Dharmayanti, I.N.L.P. 2011. Filogenetika molekuler: metode taksonomi organisme berdasarkan sejarah evolusi. Wartazoa. 1(21):1-10.

Dinas Peternakan dan Perikanan Kabupaten 
Purbalingga. 2013. Statistik Peternakan. Dinas Peternakan dan Perikanan Kabupaten Purbalingga, Purbalingga.

Hastarina, R. 2012. Keragaman Genetik Berdasarkan Polimorfisme Protein Darah dan Cytochrome b pada Burung Maleo (Macrocephalon Maleo). Universitas Diponegoro, Semarang. (Thesis).

Kimura M. 1980. A simple method for estimating evolutionary rate of base substitutions through comparative studies of nucleotide sequences. J. Mol. Evol.16:111-120.

Leary, R.F. and H.E. Booke. 1990. Starch Gel Electrophoresis and Spesies Distinction. American Fisheries Society. Bethesda, Maryland, USA. pp. 141-170.

Machugh, D.E. and D.G. Bradley. 2001. Livestock genetic origins: goat buck the trend. Proc. Natl. Acad. Sci. United State of America. 98:5382-5384.

Manceau, V., J.P. Crampe, P. Boursot and P. Taberlet. 1999. Idetification of evolutionary significant unit in the spanish wild goat, capra pyrenaica (Mamalia artiodactyla). J. Anim. Cons. 2:33-39

Mucci, N., E. Andi, L. Gentile, F. Mari and M. Cati. 1998. Mitochondrial cytochrome $b$ sequence divergence among spanish, alpine and abruzzo chamois (genus rupicapra). J. Hystrix. 10(2):29-36.

Nauli, T. 2012. Pendekatan Probabilistik pada Filogeni. Proceedings, Seminar Nasional Matematika. Pusat Penelitian Informatika LIPI . Pp 323-331.

Oka, I.G.L., W.S. Yupardhi, I.B. Mantra, N. Suyasa and A.A.S. Dewi. 2011. Genetic relationship between gembrong goat, kacang goat and kacang $\mathrm{x}$ etawah crossbred (PE) based on their mitochondrial DNA. J. Vet.
12(3):180-184.

Sambrook, J., E.F. Fritsch and T. Maniatis. 1989. Molecular Cloning. A Laboratory Manual. Cold Spring Harbour Laboratory Pr. New York.

Socheh, M., Ismaya, I.G.S. Budisatria and Kustantinah. 2011. Pengaruh flushing berbasis pakan lokal terhadap pertumbuhan dan birahi kambing kejobong betina dewasa. J. Sains Peternakan. 9(2):53-64.

Sodiq, A. and B. Haryanto. 2007. Non-genetik factor influence on doe productivity performance of local kejobong goat under village production system. J. Anim. Prod. 9 (3):123-128.

Sultana, S., H. Mannen and S. Tsuji. 2003. Mitochondrial DNA diversity of pakistani goats. J. Anim. Gen. 34:417-421

Susilowati, R. 2008. Keragaman Genetik Populasi Tiram Mutiara (Pinctada margaritifera) Berdasarkan Analisis Mitokondria. Institut Pertanian Bogor, Bogor. (Thesis).

Tamura, K., J. Dudley, M. Nei and S. Kumar. 2007. Molecular Evolutionary Genetic Analysis (MEGA) Software Version 5. Mol. Biol. Evol. 24:1596-1599.

Thompson, J.D, D. G. Higgins, T.J. Gibson. 1994. CLUSTAL W: Improving the sensitivity of progressive multiple sequence alignment through sequence weighting, Positionspecific gap penalties and weight matrix choice. Nucleic Acid Res. 22:4673-4680.

Widayanti, R., D.D. Solihin, D. Sajuthi and R.R.D. Perwitasari. 2006. Study of genetic marker on cytochrome $\mathrm{b}$ gene of Tarsius $s p$. J. Vet. Sci. 24(1):126- 132.

Woodruff, D.S. 2001. Populations, species and conservation genetics. J. Encyclopedia of Biodiversity. 4:811-829. 